\title{
Outcomes in 102 patients that present to the emergency department with chemotherapy- induced febrile neutropenia
}

\author{
Kemoterapi kaynaklı febril nötropeni şikâyetiyle acil servise başuuran \\ 102 hastanın sonuçları
}

\author{
Joo Han Lim¹, Hoon Kim², Woong Gil Choi ${ }^{3}$, Kyung Hwan Kim², Dong Wun Shin², \\ Moon Hee Lee ${ }^{1}$ \\ ${ }^{1}$ Department of Internal Medicine, Faculty of Medicine, Inha University, Incheon, Korea \\ ${ }^{2}$ Department of Emergency Medicine, Inje University Ilsan Paik Hospital, Goyang, Korea \\ ${ }^{3}$ Department of Internal Medicine, Konkuk University Hospital, Chungju, Korea
}

\begin{abstract}
Objective: Febrile neutropenia (FN) is a major toxic responseto chemotherapy requiring prompt medical attention. There are a limited number of reports on clinical outcome in patients with FN that present to emergency departments.

Materials and Methods: We retrospectively evaluated clinical manifestations, therapeutic outcomes, and risk factors for FN in 102 adult patients that presented to the emergency department between 1 January 2006 and 31 March 2009. FN was defined as a body temperature $>38^{\circ} \mathrm{C}$ and a neutrophil count $>0.5 \times 10^{9} / \mathrm{L}$ on the day of fever onset or the day after.

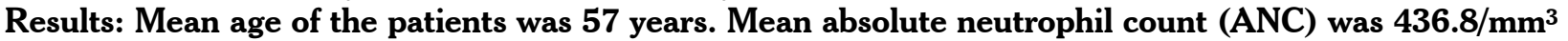
(range: $0-1000 / \mathrm{mm}^{3}$ ). In all, 23 of the patients $(22.5 \%)$ died due to complications related to FN. There were not a statistical difference in therapeutic outcome among tumor types, performance status, sex, depth of neutropenia, or time from emergency department presentationto initiation of antibiotic therapy. Age was an important prognostic factor for therapeutic outcome. Mean age of fatal cases was 65 years versus 56 years for non-fatal cases $(p=0.016)$. Bacteremia was noted in 19 patients, $10(53 \%)$ of which died. The mortality rate was significantly higher in thepatients with blood culture-proven bacteria than in those whose blood culture yielded no organism $(p=0.013)$.

Conclusion: FN patients that presented to the emergency department had a high mortality rate that increased with age. Given the increasing age of patients diagnosed with cancer as well as therapeutic interventions, the high mortality rate associated withchemotherapy-induced FN in elderly patients requires further study in order to reduce the risk of death. (Turk J Hematol 2011; 28: 193-7) Key words: Neutropenia,fever, emergency department, chemotherapy
\end{abstract}




\section{Özet}

Amaç: Febril nötropeni (FN), uygun tıbbi tedaviyi gerektiren kemoterapiye bağl gelişen önemli bir toksik yanıttır. Acil servise başvuran FN'li hastalarda klinik sonuçlara yönelik sinırlı sayıda bildiri mevcuttur.

Gereçler ve Yöntemler: 1 Ocak 2006 ile 31 Mart 2009 arasında acil servise gelen 102 erişkin FN hastasında klinik belirtiler, tedavi sonuçları ve FN için risk faktörleri geriye dönük olarak değerlendirilmiştir. FN $>38^{\circ} \mathrm{C}$ vücut sıcaklığı ve ateş başladığı gün veya ertesi günde $>0.5 \times 10^{9} / \mathrm{L}$ nötrofil sayısı olarak tanımlanmıştır.

Bulgular: Hastaların yaş ortalaması 57'dir. Ortalama mutlak nötrofil sayımı (ANC) 436.8 mm/3'dir

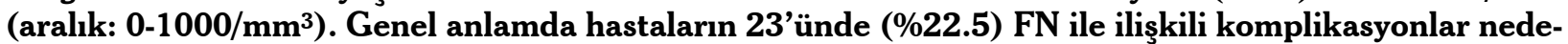
niyle ölüm meydana gelmiştir. Tümör tipleri, performans durumu, cinsiyet, nötropeni ağırlı̆̆ı veya acil duruma gelmeden antibiyotik tedavisine başlanmasına kadar geçen süre arasında tedavi sonuçları açısından istatistiksel bir fark görülmemiştir. Yaş tedavi sonuçları yönünden önemli bir prognoz faktörüdür. Ölümcül olgularda ortalama yaş 65 iken ölümcül olmayanlarda 56 'dır $(p=0.016)$. Bakteriemi 19 hastada gözlenmiş olup bunlardan 10'u ölmüştür (\%53). Kan kültürüyle bakterinin kanıtlandığı hastalarda ölüm oranı, kan kültürü ile bir organizma gösterilemeyen hastalara göre anlamlı bir şekilde daha yüksektir $(p=0.013)$.

Sonuç: Acil servise başvuran FN hastalarında yaş ilerledikçe daha yüksek bir ölüm oranı gözlenmiştir. Kanser tanısı konulan hastalarda ileri yaş ve yanı sıra tedavi girişimleri göz önüne alınarak, yaşlı hastalarda kemoterapi kaynaklı FN ile ilişkili yüksek ölüm oranının azaltılması için daha fazla çalışma gerekmektedir. (Turk J Hematol 2011; 28: 193-7)

Anahtar kelimeler: Nötropeni, ateş, acil servis, kemoterapi

\section{Introduction}

The association between neutropenia and infection, which inevitably develop following chemotherapy, is a frequent cause of morbidity and mortality in cancer patients [1,2]. Chemotherapy-induced febrile neutropenia (FN) is one of the most important and potentially life-threatening oncologic emergencies, which requires prompt medical assessment and treatment with antibiotics. In febrile patients with neutropenia, body fluids should be obtained for cultures and treatment with broadspectrum antibiotics should be started. It was recently reported that the prevalence of gram-positive infection in cancer patients with FN is increasing [3]. Although the standard of care is to treat FN as an oncologic emergency, patients generally wait for prolonged periods before receiving the necessary treatment. Prior to the present study, few data have been collected regarding the outcome of patients with FN that present to an emergency department (ED). Additional research is therefore required in order to examine the characteristics and outcome in patients that visited an ED due to chemotherapyinduced FN and to identify the risk factors associated with mortality in these patients. Accordingly, the present study retrospectively analyzed the charac- teristics and outcomes in patients with chemotherapy-induced FN that presented to our ED.

\section{Methods and Materials}

We retrospectively evaluated clinical manifestations, outcomes, and risk factors for FN following chemotherapy in 143 solid adult tumor and lymphoma patients between 1 January 2006 and 31 March 2009. Patients were selected for inclusion in the study based on the diagnosis of neutropenia and fever. Fever was defined by the criteria given in the Infectious Disease Society Guidelines, which is a fever $>38^{\circ} \mathrm{C}$ for more than $1 \mathrm{~h}$ or any single temperature measurement $>38.3^{\circ} \mathrm{C}[4,5]$. Patients that did not receive chemotherapy were excluded from the analysis, as were those that were not febrile or neutropenic. Patients whose neutropenia and fever were diagnosed in the hematology and oncology department clinics were admitted to hospital directly without an ED visit and were likewise not included in this study. We defined FN as a body temperature $>38^{\circ} \mathrm{C}$ and a neutrophil count $\leq 0.5 \times 10^{9} / \mathrm{L}$ on the same day as fever onset or the day after.

ED records for consecutive oncology patients with FN were reviewed and mortality, intensive care unit (ICU) use, blood culture results, time from ED 
presentation and administration of empirical antibiotics, and age were recorded. ED and subsequent inpatient records were also reviewed for the following: vital signs, symptoms, physical findings, suspected source of infection in the ED, white blood cell count (WBC) or absolute neutrophil count (ANC), chest radiograph results, urinalysis results, hospital course, use of granulocyte colony-stimulating factor (G-CSF), blood, urine, or other culture results, and outcome. The time from fever onset to ED presentation was defined as the time from the onset of subjective symptoms (based on patient history) and presentation to the ED. The time from ED to antibiotic administration was defined as the time from presentation to the ED and the commencement of antibiotic therapy.

\section{Treatment}

We performed blood cultures as soon as possible in patients suspected of FN in the ED. Empirical antibiotics ( $3^{\text {rd }}$ - or $4^{\text {th }}$-generation cephalosporin in combination with aminoglycoside) were administered to most of the patients. If FN was accompanied by renal insufficiency, ciprofloxacin was used as an empirical antibiotic in preference to aminoglycoside.

\section{Statistical analysis}

The survival rate, as the treatment outcome, was analyzed using the Kaplan-Meier method, with the date of presentation to the ED as the starting date. We also performed Cox regression analysis using the following variables: age, sex, time from ED presentation to the start of antibiotic therapy, the effect of G-CSF, cancer type (solid tumor or lymphoma), and performance status. All statistical analyses were conducted using SPSS v.12.0 software (SPSS, Chicago, IL). A p value of less than 0.05 was considered to be statistically significant.

\section{Results}

\section{Patient characteristics}

We analyzed 102 patients that presented to our ED due to chemotherapy-induced FN between 1 January 2006 and 31 March 2009. The characteristics of these patients are summarized in Table 1. The Eastern Cooperative Oncology Group (ECOG) performance status of the patients was as follows: 20 patients had a performance status of 2,67 had a performance status of 1 , and 15 had a performance status of 0 . Mean age of the patients was 57 years (range: $25-84$ years) and 53\% were male. Mean ANC was $436.8 \mathrm{~mm}^{3}$ (range: $0-1000 \mathrm{~mm}^{3}$ ); 4 patients had an ANC $<10 \mathrm{~mm}^{3}$.

\section{Treatment and survival outcome}

Survival of elderly patients $(\geq 65)$ was inferior to that of the younger patients $(<65)$. Mean age of the patients that died due to an FN event (65 years) was significantly $(p=0.016)$ higher than that of the patients that didn't (56 years). There wasn't a difference in the outcome of FN between patients with lymphomas and those with solid tumors. Median time from the onset of fever to ED presentation was $24 \mathrm{~h}$; the difference between the patients that died and survived was not significant (Table 2). We also analyzed the patients according to those that presented to the ED within $24 \mathrm{~h}$ of the onset of fever and after $24 \mathrm{~h}$; however, there wasn't a significant difference in outcome between these 2 groups. Median time from ED presentation to the start of antibiotic therapy was approximately $2 \mathrm{~h}$ (110 min; range: 0.6-13.3 h), and there wasn't a significant difference between the patients that died and those that survived.

Table 1. Patient characteristics

\begin{tabular}{|c|c|}
\hline Total Patients & $\mathrm{n}=102$ \\
\hline \multicolumn{2}{|l|}{ Sex } \\
\hline Male & $50(49 \%)$ \\
\hline Female & $52(51 \%)$ \\
\hline Median age, years & 57 \\
\hline \multicolumn{2}{|l|}{ Cancer Type } \\
\hline Lymphoma & $30(29.4 \%)$ \\
\hline Solid Tumor & $72(70.6 \%)$ \\
\hline ANC median, number $/ \mathrm{mm}^{3}$ & 90 (range; 5-760) \\
\hline $\mathrm{ANC} \leq 100 \mathrm{~mm}^{3}$ & $53(52 \%)$ \\
\hline ANC $>100 \mathrm{~mm}^{3}$ & $49(48 \%)$ \\
\hline \multicolumn{2}{|l|}{ Symptom to ED time } \\
\hline$\leq 24 \mathrm{hr}$ & $49(48 \%)$ \\
\hline$>24 \mathrm{hr}$ & $53(52 \%)$ \\
\hline Median ED to Antibiotics time (min) & 110 (range; 35-615) \\
\hline \multicolumn{2}{|l|}{ Blood culture result } \\
\hline Bacteremia & $19(18.6 \%)$ \\
\hline gram-positive & $6(5.9 \%)$ \\
\hline gram-positive & $13(512.7 \%)$ \\
\hline No growth & $80(70.4 \%)$ \\
\hline No culture & $3(2.9 \%)$ \\
\hline
\end{tabular}


Among the patients that presented to the ED outside regular working hours, the time from ED presentation to the start of antibiotic therapy was longer than that in patients that presented during regular working hours; however, the difference was not statistically significant and there was no difference in the outcome of FN. In all, 24 patients (23.5\%) required ICU management, of which 18 (75\%) died due to complications associated with FN. Patients with FN that required ICU care had a significantly higher mortality rate than those did not require ICU care $(p<0.05)$. Patients treated in the ICU were older than those treated in a general ward (median age: 68 vs. 55 , respectively).

We also analyzed the relationship between blood culture positivity and treatment outcome. In total, 19 patients had blood culture-positive results; 6 had gram-positive bacteremia and 13 had gram-negative bacteremia. Figure 1 shows the microorganisms isolated via blood culture. The 19 patients with bacteremia were initially treated with the 3rd-generation antibiotics cephalosporin and aminoglycoside, except 2 patients highly suspected for grampositive infection (1 patient had phlebitis and 1 patient had catheter-related infection). The mortality rate was significantly higher among the culturepositive patients than among those whose blood culture yielded no organism (47.4\% versus $16.3 \%$, $\mathrm{p}=0.013$ ). In total, 23 patients died due to an infection associated with FN. The patients that died were significantly older than those that survived.

\section{Discussion}

Chemotherapy-induced neutropenia is a common toxicity that increases patient risk of morbidity and mortality, and may compromise the effectiveness of treatment via a reduction in chemotherapy dose intensity or dose density [6]. In the present study advanced age, necessity of ICU care, and bacteremia (confirmed by blood culture) were risk factors for mortality in the patients that presented to our ED with chemotherapy-induced FN. Intensive education for patients that receive chemotherapy began at our hospital in 2005. The education we provide includes information on nutrition, chemotherapy toxicity, and conditions that should prompt presentation to hospital. A fever $>38^{\circ} \mathrm{C}$ is emphasized as a major side effect that necessitates immediate medical
Table 2. Comparison of the patients that died and survived

\begin{tabular}{lccc}
\hline & Survived & Died & p \\
\hline Age (years) & $56(25-84)$ & $65(45-84)$ & 0.016 \\
Blood Culture Results & $\mathrm{n}$ & $\mathrm{n}$ & \\
$\quad$ Bacteremia & 10 & 9 & 0.013 \\
$\quad$ non-bacteremia & 67 & 13 & \\
Cancer Type & $\mathrm{n}$ & $\mathrm{n}$ & \\
$\quad$ Lymphoma & 22 & 8 & 0.521 \\
Solid & 57 & 15 & \\
Absoulte Neutrophil Count & $\mathrm{n}$ & $\mathrm{n}$ & \\
ANC $<100$ & 44 & 9 & 0.162 \\
ANC $>100$ & 35 & 14 & \\
Time of symptom to ED & $\mathrm{n}$ & $\mathrm{n}$ & \\
$\quad$ Symptom to ED $<24 \mathrm{~h}$ & 52 & 13 & 0.414 \\
Symptom to ED $>24 \mathrm{~h}$ & 27 & 10 & \\
\hline
\end{tabular}



Figure 1. Culture results isolated in the patients with bacteremia

assessment; however, only 34 of the patients in the present study received individual education regarding chemotherapy and its toxicity. There was a statistically significant difference in outcome between the patients that received education and those that did not. It would nevertheless be imprudent to conclude that intensive education contributed to the survival of patients with FN; however, there is no doubting the value of education for cancer patients scheduled to receive cytotoxic chemotherapy.

Many researchers are now exploring alternatives to the standard approach to treating FN, including prophylactic oral antibiotic treatment, administration of prophylactic hematopoietic growth factors, and even oral antibiotic therapy for low-risk outpatients [7-10].

As the present study used retrospective analysis of data obtained at only 1 academic institution that treats patients with malignancies, it might not 
reflect care in the community at large or that at other institutions. The retrospective design of the present study and the small sample involved should be taken into account when making inferences and recommendations based on the findings.

In conclusion, we analyzed the outcome of patients that presented to our ED due to chemotherapy-induced FN. We observed considerable mortality, particularly in the elderly patients. Given the increasing age of adults diagnosed with cancer that undergo chemotherapy, and the heightened risk of FN among elderly patients, further prospective studies are warranted in order to establish a more appropriate management strategy for chemotherapy-induced FN, and for reducing the incidence of mortality and morbidity due to chemotherapy.

\section{Acknowledgment}

IRB committee of Inha university hospital approved our study. IRB committee approval is same an ethical committee approval.

\section{Conflict of interest statement}

The authors of this paper have no conflicts of interest, including specific financial interests, relationships, and/or affiliations relevant to the subject matter or materials included.

\section{References}

1. Weycker D, Malin J, Kim J, Barron R, Edelsberg J, Kartashov A, et al. Risk of hospitalization for neutropenic complications of chemotherapy in patients with primary solid tumors receiving pegfilgrastim or filgras- tim prophylaxis: a retrospective cohort study. Clin Ther 2009,31:1069-81.

2. Caggiano V, Weiss RV, Rickert TS, Linde-Zwirble WT. Incidence, cost, and mortality of neutropenia hospitalization associated with chemotherapy. Cancer 2005;103:1916-24.

3. Zinner SH. Changing epidemiology of infections in patients with neutropenia and cancer: emphasis on gram-positive and resistant bacteria. Clin Infect Dis. 1999,29:490-4.

4. Paul M, Gafter-Gvili A, Leibovici L, Bishara J, Levy I, Yaniv I, et al. The epidemiology of bacteremia with febrile neutropenia: experience from a single center, 1988-2004. Isr Med Assoc J 2007;9:424-9.

5. Rabagliati BR, Fuentes LG, Orellana UE, Oporto CJ, Dominguez MI, Benitez GR, et al. [Etiology of febrile neutropenia episodes among cancer patients from Hospital Clinico Universidad Catolica, Santiago-Chile.]. Rev Chilena Infectol 2009;26:106-13.

6. Lyman GH, Lyman CH, Agboola O. Risk models for predicting chemotherapy-induced neutropenia. Oncologist 2005,10:427-37.

7. Zinner SH. Changing epidemiology of infections in patients with neutropenia and cancer: emphasis on gram-positive and resistant bacteria. Clin Infect Dis 1999,29:490-4.

8. Marti FM, Cullen MH, Roila F. Management of febrile neutropenia: ESMO clinical recommendations. Ann Oncol 2009,4:166-9.

9. Timmer-Bonte JN, Tjan-Heijnen VC. Febrile neutropenia: highlighting the role of prophylactic antibiotics and granulocyte colony-stimulating factor during standard dose chemotherapy for solid tumors. Anticancer Drugs 2006;17:881-9.

10. Herbst C, Naumann F, Kruse EB, Monsef I, Bohlius J, Schulz H, et al. Prophylactic antibiotics or G-CSF for the prevention of infections and improvement of survival in cancer patients undergoing chemotherapy. Cochrane Database Syst Rev 2009;CD007107. 